\title{
PENGARUH BAURAN PEMASARAN TERHADAP KEPUTUSAN PEMBELIAN PRODUK PASTA GIGI PEPSODENT DI KECAMATAN BANJARMASIN BARAT
}

\author{
Zenni Ariantini \\ Zenniariyanti.za@gmail.com \\ Erni Alfisah \\ alfisaherni@gmail.com \\ Muthia Harnida \\ raissa-kembar@yahoo.co.id
}

Universitas Islam Kalimantan MAB Banjarmasin

\begin{abstract}
The aim of this research is to investigate the effect of mix marketing which consists of product, price, distribution, and promotion on the purchace of Pepsodent product at the district of West Banjarmasin.

This research is a survey using 100 people as respondents. The data is analyzed using multiple regression analysis. The result of this research indicated that the mix marketing of product, distribution, and promotion statistically have significant effect on purchacing the pepsodent product at the district of west Banjarmasin. But, the price in the result of this research statistically could not give the evidence of its effect on purchasing the pepsodent product for the consumers at the district West Banjarmasin .
\end{abstract}

Key words: Mix marketing, price, product, promotion, purchasing

\section{PENDAHULUAN}

Dunia bisnis berkembang dan berkompetisi semakin pesat dan ketat. Produk-produk pasta gigi yang ada di pasaran dewasa ini sangat beragam baik jenis maupun mereknya. Pepsodent sebagai salah satu merek pasta gigi di Indonesia yang sudah cukup lama dikenal masyarakat dan bisa dikatakan salah satu produk pasta gigi yang sangat dikenal masyarakat. Produk pasta gigi ini bahkan telah melakukan beberapa strategi pengembangan produk yaitu line extention dan brand extention. Line extention adalah salah satu strategi pengembangan produk dengan memperkenalkan produk baru yang berbeda namun tetap dalam kategori yang sama seperti rasa, bentuk, warna, dan kemasan.

Fakta menunjukkan bahwa Pepsodent telah melakukan Integrated Marketing Communication dengan baik, dan memiliki market share terbesar dalam industri pasta gigi di Indonesia. Berdasarkan hasil jajak pendapat yang 
diadakan Top BrandAward (2014), pepsodent adalah pasta gigi yang paling banyak digunakan yakni 71,06\%, Close Up sebesar $11.04 \%$, Sensodyne sebesar $5.60 \%$, Formula $3.52 \%$, Ciptadent $2.73 \%$ dan sisanya merek lain sebesar $5.74 \%$. Hal inilah yang juga melatarbelakangi penelitian ini untuk menguji faktorfaktor apa saja yang mempengaruhi konsumen dalam memilih produk pasta Gigi Merek Pepsodent ini yang ada dalam bauran pemasaran yang meliputi produk, harga, saluran distribusi dan promosi. Penelitian ini bertujuan untuk menguji apakah produk, harga, saluran distribusi dan promosi berpengaruh terhadap keputusan pembelian pasta gigi Merek Pepsodent pada konsumen rumah tangga yang berada di wilayah Kecamatan Banjarmasin Barat.

\section{TINJAUAN PUSTAKA}

\section{Bauran Pemasaran}

Pengertian bauran pemasaran seperti yang dikemukakan oleh Kotler (2005), mendefinisikan bauran pemasaran adalah seperangkat alat pemasaran yang digunakan perusahaan Bauran pemasaran adalah seperangkat alat pemasaran yang digunakan perusahaan untuk terus-menerus mencapai tujuan pemasarannya di pasar sasaran", sedangkan Cravens (2000) menyatakan "Bauran pemasaran mengacu pada paduan strategi produk, distribusi, promosi dan penentuan harga yang bersifat unik yang dirancang untuk menghasilkan pertukaran yang saling memuaskan dengan pasar yang dituju".

\section{Produk}

Secara konseptual, produk adalah pemahaman subjektif dari produsen atas sesuatu yang bisa ditawarkan sebagai usaha untuk mencapai tujuan organisasi melalui pemenuhan dan keinginan konsumen, sesuai dengan kompetensi dan kapasitas organisasi serta daya beli pasar.Menurut Lamb et al. (2001) "Produk tidak hanya meliputi fisiknya saja tetapi juga kemasan, garansi, pelayanan purna jual, merek, nama baik perusahaan, dan nilai kepuasan”.Selain itu, Kotler (2000), menyatakan "Merencanakan penawaran pasar atau produk, pemasar harus memikirkan lima tingkatan produk".Kelima tingkatan tersebut dapat disajikan pada Gambar 2.1 . 


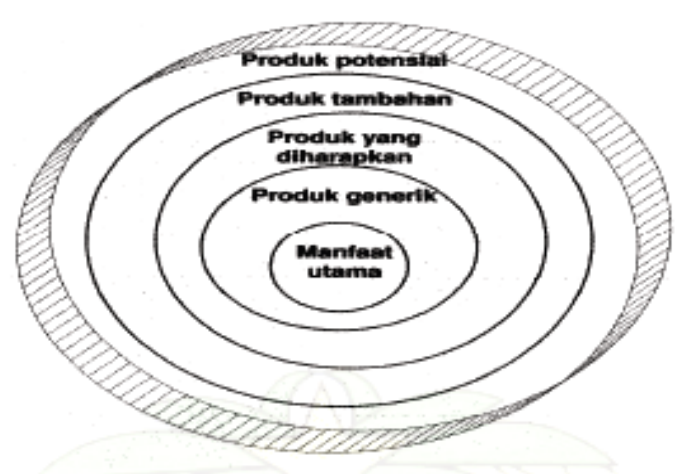

Sumber: Kotler (2000)

Gambar 2.1 Lima Tingkat Produk

Gambar 2.1 menunjukkan tingkat paling dasar adalah manfaat utama (manfaat dasar) suatu produk yang sesungguhnya dibeli oleh konsumen.Kedua pemasar harus dapat merubah manfaat utama menjadi produk generik. Pada tingkat ke tiga pemasar mempersiapkan produk yang diharapkan yaitu satu set atribut dan persyaratan yang biasanya diharapkan dan disukai oleh konsumen ketika melakukan pembelian. Tingkatan ke empat pemasar mempersiapkan produk tambahan yaitu meliputi tambahan jasa dan manfaat yang akan membedakannya dari pesaing serta pada tingkat ke lima adalah produk potensial, yaitu semua tambahan dan perubahan yang mungkin diperoleh dari produk tersebut. Dengan adanya produk tambahan diharapkan semua kebutuhan yang diinginkan oleh konsumen dapat terpenuhi sesuai dengan kebutuhan yang diinginkan oleh konsumen akhir.

\section{Harga}

Menurut Lamb et al. (2001) "Harga adalah apa yang harus diberikan oleh konsumen (pembeli) untuk mendapatkan suatu produk".Harga sering merupakan elemen yang paling fleksibel di antara keempat elemen bauran pemasaran.Selain itu, Walker, et al. (2000) "Menerapkan kebijakan harga rendah dibandingkan dengan pesaing dapat diciptakan, apabila perusahaan memiliki keunggulan bersaing pada biaya rendah (low cost)".Demikian halnya menurut Kotler (2005) "Penetapan harga dan persaingan harga merupakan masalah nomor satu yang dihadapi oleh para eksekutif pemasaran“

Payne (2001) menyatakan

"Keputusan-keputusan penetapan harga sangat signifikan dalam menentukan nilai bagi pelanggan dan memainkan peran sangat penting dalam pembentukan citra bagi jasa tersebut". Purnama (2001) menyatakan suatu perusahaan harus menetapkan harga untuk pertama kalinya, yakni ketika;

(1) Perusahaaan tersebut mengembangkan atau memperoleh suatu produk baru.

(2) Perusahaan tersebut baru pertama kalinya memperkenalkan produk 
regulernya ke saluran distribusi atau daerah baru.

(3) Perusahaan akan mengikuti lelang atas suatu kontrak kerja baru.

Harga merupakan satu-satunya unsur bauran pemasaran yang memberikan pemasukan atau pendapatan bagi perusahaan.Menurut Stanton (1996) "Harga adalah sejumlah uang yang dibutuhkan untuk memperoleh beberapa kombinasi sebuah produk dan pelayanan yang menyertainya". Tingkat harga yang ditetapkan mempengaruhi kuantitas yang terjual.Selain itu, secara tidak langsung harga juga mempengaruhi biaya, karena kuantitas yang terjual berpengaruh pada biaya yang ditimbulkan dalam kaitannya dengan efisiensi produksi. Dalam beberapa riset yang telah dilakukan oleh para peneliti terdahulu, harga merupakan salah satu variabel dari bauran pemasaran yang juga memengaruhi keputusan pembelian terhadap suatu produk tertentu. Saputra (2013) meneliti tentang pengaruh bauran pemasaran terhadap keputusan pembelian produk furniture yang mengambil studi kasus pada PT. Regalindo Sidoarjo.

\section{Saluran Distribusi}

Menurut Kotler (2000) "Saluran distribusi adalah serangkaian organisasi yang saling tergantung yang terlibat dalam proses untuk menjadikan produk atau jasa siap untuk digunakan atau dikonsumsi".Cravens (2000) menyatakan "Keputusan untuk menggunakan saluran distribusi yang menyangkut masalah jenis organisasi saluran yang akan digunakan, peningkatan manajemen saluran distribusi, dan intensitas distribusi sesuai dengan produk”.

Saluran distribusi menghubungkan produsen dengan pengguna akhir produk atau jasa.Saluran distribusi yang efektif dan efesien memberikan keunggulan strategi yang penting bagi para anggota organisasi atas saluransaluran pesaingnya.

$$
\text { Cravens (2000) menyatakan }
$$

"Saluran distribusi adalah jaringan organisasi yang melakukan fungsi-fungsi yang menghubungkan produsen dengan konsumen akhir".Saluran distribusi terdiri dari berbagai lembaga atau badan yang saling tergantung dan saling berhubungan, yang berfungsi sebagai suatu sistem atau jaringan, yang bersama-sama berusaha menghasilkan dan mendistribusikan sebuah produk kepada konsumen akhir.

Pemasaran lokal produk Pasta gigi yang telah dikemas dan telah 
memiliki merek (brand), disalurkan melalui saluran distribusi tidak langsung atau melalui perantara, terutama target pasar konsumen akhir. Strategi distribusi berkenaan dengan bagaimana sebuah perusahaan menjangkau pasar sasarannya, sebagian produsen memasarkan produknya secara langsung kepada konsumen akhir, sedangkan sebagian lagi memasarkan produknya melalui satu atau lebih saluran distribusi.

\section{Promosi}

Strategi promosi adalah perencanaan, implementasi, dan pengendalian komunikasi dari suatu organisasi kepada para konsumen dan sasaran lainnya.Fungsi promosi dalam bauran pemasaran adalah untuk mencapai berbagai tujuan komunikasi dengan setiap konsumen.

Cravens (2000) menyatakan "Strategi promosi mencakup penentuan: (1) tujuan komunikasi, (2) peranan komponen-komponen pembentuk bauran promosi, (3) anggaran promosi, dan (4) strategi setiap komponen bauran". Komponen-komponen bauran promosi mencakup periklanan, penjualan perorangan, promosi penjualan, dan hubungan masyarakat.Tanggung jawab pemasaran yang penting adalah merencanakan dan mengkoordinasikan strategi promosi terpadu dan memilih strategi yang paling efektif. Dalam rangka merancang komunikasi pemasaran yang efektif, setiap pemasaran perlu memahami proses komunikasi secara umum yaitu: pelaku komunikasi (pengirim dan penerima pesan), alat komunikasi (pesan dan media), fungsi komunikasi (encoding, decoding, respons dan umpanbalik), serta gangguan.

Promosi seperti iklan, promosi penjualan, penjualan personal, dan hubungan masyarakat (public relations), semuanya digunakan untuk membantu perusahaan berkomunikasi dengan konsumennya, menjalin kerjasama antar organisasi, masyarakat dan sasaran lainnya. Menurut Cravens (2000) "Promosi memainkan peranan yang sangat penting dalam menempatkan posisi di mata dan benak pembeli, karena promosi pada hakekatnya untuk memberitahukan, mengingatkan, membujuk pembeli serta pihak lain yang berpengaruh dalam proses pembelian.

\section{METODE PENELITIAN}

Jenis penelitian adalah penelitian kuantitatif yakni untuk menguji pengaruh bauran pemasaran terhadap 
Volume 4 Nomor 1, April 2018

keputusan pembelian Pasta Gigi Keterangan:

Pepsodent. Metode yang digunakan $\quad \mathrm{Y}=$ Keputusan Pembelian produk Pasta

dalam penelitian ini yaitu menggunakan Gigi Pepsodent $\mathrm{a}=$ Konstanta.

teknik random sampling, dengan $b=$ koefisien regresi

responden sebanyak 100 orang. $\quad \mathrm{X} 1=$ produk.

Data dianalisis dengan $\mathrm{X} 2=$ harga,

menggunakan analisis Regresi Linier $\mathrm{X} 3=$ Saluran distribusi,

Berganda di mana $\mathrm{Y}=\mathrm{a}+\mathrm{b} 1 \mathrm{X} 1+\mathrm{b} 2 \quad \mathrm{X} 4=$ promosi,

$\mathrm{X} 2+\mathrm{b} 3 \mathrm{X} 3+\mathrm{b} 4 \mathrm{X} 4+€ \quad €=$ standar eror.

\section{HASIL PENELITIAN DAN PEMBAHASAN}

\section{Hasil pengujian koefisien determinasi}

Tabel 2 Koefisien determinasi

Model Summaryb

\begin{tabular}{|l|r|r|r|r|}
\hline Model & \multicolumn{1}{|c|}{$\mathrm{R}$} & R Square & \multicolumn{1}{|c|}{ Adjusted R Square } & \multicolumn{1}{c|}{ Std. Error of the Estimate } \\
\hline 1 & $.742^{\mathrm{a}}$ & .550 & .531 & 1.321 \\
\hline
\end{tabular}

a. Predictors: (Constant), Promosi, Harga, Produk, Distribusi

b. Dependent Variable: Keputusan_Pembelian

Hasil koefisien diterminasi menunjukkan bahwa 55 persen variabel yang digunakan dalam penelitian ini dapat menjelaskan hubungan antara variabel dependen yakni keputusan pembelian produk pasta gigi pepsodent dengan ke empat variabel bebasnya, yakni produk, harga, saluran distribusi dan promosi , sedangkan sisanya sebesar 45 persen dipengaruhi oleh variabel yang lain di luar model penelitian.

\section{Hasil Pengujian Hipotesis}

Tabel 3 Hasil Uji Serempak

ANOVA $^{\text {b }}$

\begin{tabular}{|ll|r|r|r|r|r|}
\hline Model & & Sum of Squares & df & Mean Square & F & Sig. \\
\hline 1 & Regression & 202.847 & 4 & 50.712 & 29.058 & $.000^{a}$ \\
& Residual & 165.793 & 95 & 1.745 & & \\
& Total & 368.640 & 99 & & & \\
\hline
\end{tabular}

a. Predictors: (Constant), Promosi, Harga, Produk, Distribusi

b. Dependent Variable: Keputusan_Pembelian 
Dari Tabel 3 diperoleh nilai $p$-value dibawah alpha 0,05, sehingga dapat dikatakan bahwa secara secara serempak variabel produk, harga, saluran distribusi dan promosi berpengaruh terhadap keputusan pembelian produk pasta gigi pepsodent oleh konsumen rumah tangga di Kecamatan Banjarmasin barat.

Tabel 4 Hasil Uji parsial

Coefficients $^{a}$

\begin{tabular}{|c|c|c|c|c|c|c|c|c|}
\hline \multirow{2}{*}{\multicolumn{2}{|c|}{ Model }} & \multicolumn{2}{|c|}{$\begin{array}{l}\text { Unstandardized } \\
\text { Coefficients }\end{array}$} & \multirow{2}{*}{$\begin{array}{c}\begin{array}{c}\text { Standardized } \\
\text { Coefficients }\end{array} \\
\text { Beta }\end{array}$} & \multirow[b]{2}{*}{$\mathrm{t}$} & \multirow[b]{2}{*}{ Sig. } & \multicolumn{2}{|c|}{ Collinearity Statistics } \\
\hline & & B & Std. Error & & & & Tolerance & VIF \\
\hline & (Constant) & .213 & 1.489 & & .143 & .886 & & \\
\hline & Produk & .357 & .077 & .332 & 4.666 & .000 & .935 & 1.069 \\
\hline & Harga & -.017 & .096 & -.022 & -.179 & .858 & .317 & 3.157 \\
\hline & Distribusi & .353 & .114 & 386 & 3.100 & .003 & .306 & 3.273 \\
\hline & Promosi & .283 & .057 & .388 & 4.990 & .000 & .784 & 1.275 \\
\hline
\end{tabular}

a. Dependent Variable: Keputusan_Pembelian

Hasil pengujian secara parsial sebagaimana yang tampak pada table 4 di atas, menunjukkan bahwa variabel yang berpengaruh terhadap keputusan pembelian produk pasta gigi pepsodent oleh konsumen rumah tangga di Kecamatan Banjarmasin Barat adalah variabel produk, distribusi, dan promosi di mana terlihat bahwa secara statistik nilai $p$-value nya berada di bawah alpha 0,05. Dengan demikian hipotesis yang menyatakan bahwa produk, saluran distribusi dan promosi berpengaruh terhadap keputusan pembelian produk pasta gigi pepsodent oleh konsumen rumah tangga di kecamatan Banjarmasin Barat dapat diterima. Hal ini diakibatkan merk pepsodent sudah lama dikenal masyarakat dan secara terus menerus produk ini juga mengalami perbaikan dan melakukan diversifikasi produk sehingga masyarakat merasakan kebutuhannya dapat dipenuhi oleh merk ini sehingga pepsodent mampu mengungguli para pesaingnya. Hasil penelitian ini juga sejalan dengan pendapat Kartajaya (2000) "Produk harus diperbaiki terus menerus supaya konsumen tidak berpaling ke pesaing”.

Saluran distribusi secara statistik juga berpengaruh terhadap keputusan pembelian produk pasta gigi. Hal ini bisa disebabkan pasta gigi Pepsodent mudah untuk diperoleh atau dibeli karena dapat ditemui hamper di setiap toko, warung, dan swalayan yang ada di Kecamatan Banjarmasin Barat. Demikian juga halnya dengan variabel promosi yang 
Volume 4 Nomor 1, April 2018

hasilnya secara statistik juga

Dalam penelitian ini variabel menujukkan pengaruh terhadap keputusan pembelian produk pasta gigi pepsodent oleh konsumen rumah tangga di Kecamatan Banjarmasin Barat . Hal ini disebabkan karena intensitas iklan pasta gigi Pepsodent di media elektronik seperti televisi lebih tinggi dibandingkan dengan produk sejenis. Pengaruh iklan yang ditayangkan melalui media televisi sangat mempengaruhi para konsumen. Hasil penelitian ini sejalan dengan apa yang dikemukakan oleh Walker, et al. (2000) "Promosi memainkan peranan yang sangat penting dalam menempatkan posisi di mata dan benak pembeli, karena promosi pada hakekatnya untuk memberitahukan, mengingatkan, membujuk pembeli serta pihak lain yang berpengaruh dalam proses pembelian". Hasil penelitian ini juga sesuai dengan hasil penelitian Adam (2006) "Biarpun promosi yang dilakukan masih terbatas pada periklanan dengan menggunakan media televisi, radio, dan bilboard, karena ratarata konsumen rumah tangga mengetahui merek Pasta gigi dari media tersebut, walaupun pada tingkat kejelasan informasi tentang manfaat Pasta gigi belum begitu jelas diterima". 
tersebut adalah variabel produk, saluran distribusi dan promosi, sedangkan variabel harga dalam hasil penelitian ini tidak berpengaruh terhadap keputusan pembelian produk pasta gigi pepsodent oleh konsumen rumah tangga di Kecamatan Banjarmasin Barat.

\section{DAFTAR PUSTAKA}

Cravens, David W. 2000, Pemasaran Strategis , Edisi Keempat, Alih Bahasa: Lina Salim, Penerbit Erlangga, Jakarta.

Engel, James F., Blackwell, Roger D., and Miniard, Paul W. 1994, Perilaku Konsumen. Terjemahan: Budiyanto, Penerbit Binarupa Aksara, Jakarta.

Kartajaya, Hermawan. 2000. Marketing Plus 2000: Siasat Memenangkan Persaingan Global, Penerbit PT. Gramedia Pustaka Utama, Jakarta.

Kotler, Philip. 2005, Manajemen Pemasaran, Terjemahan: Hendra Teguh, Ronny A. Rusli dan Benjamin Molan, Edisi Milenium, Penerbit PT. Indeks, Jakarta. dan Armstrong .2001, Prinsip-Prinsip Pemasaran, Jilid I, Edisi Kedelapan, , Penerbit Erlangga, Jakarta.

.2000 Manajemen Pemasaran di Indonesia, Edisi Pertama, Terjemahan: AB. Susanto, Penerbit Salemba Empat, Jakarta.
Lamb, Chales W., Hair, Joseph F., and McDaniel, Carl. 2001, Pemasaran, Buku Pertama, Penerjemah: David Octarevia, Penerbit Salemba Empat, Jakarta.

Lupiyoadi, Rambat. 2006, Manajemen Pemasaran Jasa: Teori dan Praktek, Edisi Pertama, Penerbit Salemba Empat, Jakarta.

Nazir, Moh. 2003, Metode Penelitian, Cetakan Kelima, Penerbit Ghalia Indonesia, Jakarta.

Payne, Adrian. 2001, The Essence of Service Marketing, Diterjemahkan oleh: Fandy Ciptono, Penerbit Andi, Yogyakarta.

Peter, J Paul., and Olson., Jerry C,. 2000. Consumer Behavior: Perilaku Konsumen dan Strategi Pemasaran. Diterjemahankan oleh: Damos Sihombing, Jilid 1. Edisi Keempat, Penerbit Erlangga, Jakarta.

Purnama, Lingga. 2001, Strategi Marketing Plan, Penerbit PT. Gramedia Pustaka Utama, Jakarta.

Santoso, Singgih. 2001, Mengolah Data Statistik Secara Profesional, PT. Elex Media Komputindo, Jakarta.

. 2000, Buku Latihan SPSS Statistik Parametrik, Penerbit PT. Elex Media Komputindo, Jakarta.

Sekaran, Uma . 2006, Metode Penelitian untuk Bisnis, Edisi Keempat, Penerjemah: Kwan Men Yon, Penerbit Salemba Empat, Jakarta. 
Stanton, William J. 1996, Prinsip Pemasaran, Edisi Ketujuh, Alih Bahasa: Y. Lamarto, Penerbit Erlangga, Jakarta.

Sugiyono. 2002, Metode Penelitian Bisnis, Cetakan Pertama, Penerbit Alfabeta, Bandung.

Swastha, Basu. 1996, Azas-Azas Marketing, Edisi Ketiga, Penerbit BPFE, Yogyakarta.

Umar, Husein. 2003, Metode Riset Bisnis, Cetakan Pertama, Penerbit PT. Gramedia Pustaka Utama, Jakarta.

Walker, Orville C., Boyd, Harper W., Larreche, Jean Claude. 2000, Manajemen Pemasaran: Suatu Pendekatan Strategi dengan Orientasi Global, Jilid II Edisi Kedua, Alih Bahasa: Imam Nurmawan, Penerbit Erlangga, Jakarta.

Winardi. 2001, Manajemen Pemasaran, Penerbit CV. Sinar Baru, Bandung.

Fitriana, Nana. 2002, Pengaruh Gaya Pelaksanaan Pesan Pasta gigiPepsodent Melalui Media TV Pada Pembelian Pasta gigi Masyarakat di Kelurahan Sumbersari Kecamatan Lowok Waru Kota Malang, Tesis, Universitas Muhamadiyah Malang, Malang.

P. Adam, Rosida. 2006, Pengaruh Faktor Internal Konsumen dan Kinerja Bauran Pemasaran Terhadap Keputusan Pembelian Komoditi Pasta gigi oleh Konsumen Rumah Tangga di Provinsi Jawa Barat, Desertasi,
Universitas Padjadjaran, Bandung.

Ramli, Abdul. 2007, Keunggulan Pasta GigiPepsodent, http://www. pintunet.com, dikunjungi tanggal tanggal 14 September 2017.

Sarah, Dina. 2007, Sejarah dan Perkembangan Pasta gigi, http://www. wikipedia indonesia.co.id dikunjungi tanggal 14 September 2017.

Subarna, Nana, dan Suryadi, Dadang.1999, Pengaruh UnsurUnsur Produk Mix Pasta gigi Terhadap Harga dan Jumlah Konsumsi Konsumen dalam Rumah Tangga, Sosio Ekonomi Balai Penelitian Pasta gigi Dan Kina, Gambung.

Suryadi, Dadang, Subarna, Nana, Rosyadi, A. Imron, dan Awalina, Nurul. 2002, Pengaruh Iklan Terhadap Prilaku Pembelian Konsumen Pasta gigi dalam Keluarga, Jurnal Agro Ekonomi, Vol. 20 N0.2, Pusat Penelitian dan Pengembangan Sosial Ekonomi Pertanian, Bogor.

Wulandari, Rina. 2007, Profil PT. Unilever Indonesia Tbk, http://www. sinarharapan.co.id, dikunjungi tanggal 14 September 2017.

https://blog.jakpat.net/hasil-surveypasta-gigi-pepsodent-atau-yanglain/ 